\title{
Do Participatory Leadership Style, Motivation, and Work Environment Affect Employee Performance? Lessons from Local Organization in An Emerging Country
}

\author{
Endah Suryani ${ }^{1}$, Ferdinandus Christian ${ }^{2}$, Mohammad Imam Farisi ${ }^{3}$ \\ 1,2,3Faculty of Economics, Universitas Terbuka, Indonesia \\ Email: endahsuryani@gmail.com, tamehi68@gmail.com,imamfarisi@ecampus.ut.ac.id
}

\begin{abstract}
:
This study aims to determine the effect of participatory leadership style, motivation and work environment on employee performance at the Department of Public Works and Public Housing (PUPR) of Yapen Islands Regency, Papua, Indonesia. This research is a quantitative research with the sources of data collected in this study are primary data and secondary data. This study used a saturated sample with a total of 101 people and applied multiple regression to analyse the data. It found that the participatory leadership did not affect the employee performance, while motivation and work environment influence the employee performance. It implies that the latter variables are the employee performance's key drivers and should be the main priorities.
\end{abstract}

Keywords: participatory leadership style; work motivation; work environment; employee performance; PUPR Yapen

\section{Introduction}

Performance issues are currently a serious concern for every government agency and local government organization in Indonesia (Jurnali \& Siti-Nabiha, 2015). This fact can be seen from the government's efforts to organize the public officers (Wahjusaputri \& Fitriani, 2017) and the many policies issued to discipline them (Suyuti \& Kasmita, 2018). It shows the policies taken by the government of a worker management system based on performance-based management, namely the existence of a Government Agency Performance Accountability System Report (Sugianto, 2017).

The observed local organization, the Department of Public Works and Public Housing (PUPR) of the Yapen Islands Regency, has the task of assisting the regent in carrying out government affairs in the field of public works and public housing, which is the regional authority and the assistance tasks given to the district. While its organizational performance is not optimal yet, as shown in Table 1 . 
Table 1. LAKIP PUPR Office of Yapen Islands Regency in 2019

\begin{tabular}{|c|c|c|c|c|}
\hline No & Strategic target & Performance Indicator & Target & Realization \\
\hline 1 & $\begin{array}{l}\text { Office administration service } \\
\text { program }\end{array}$ & $\begin{array}{l}\text { The creation of good } \\
\text { office administration }\end{array}$ & $100 \%$ & $96 \%$ \\
\hline 2 & $\begin{array}{l}\text { Apparatus facilities and } \\
\text { infrastructure improvement } \\
\text { program }\end{array}$ & $\begin{array}{l}\text { Adequate and good } \\
\text { apparatus facilities and } \\
\text { infrastructure }\end{array}$ & $100 \%$ & $55 \%$ \\
\hline 3 & $\begin{array}{l}\text { Apparatus discipline } \\
\text { improvement program }\end{array}$ & $\begin{array}{l}\text { Discipline using office } \\
\text { uniform seragam }\end{array}$ & $100 \%$ & $100 \%$ \\
\hline 4 & $\begin{array}{l}\text { Program to improve the } \\
\text { development of performance } \\
\text { and financial performance } \\
\text { reporting systems }\end{array}$ & $\begin{array}{l}\text { Accuracy of financial } \\
\text { statements }\end{array}$ & $100 \%$ & $100 \%$ \\
\hline 5 & $\begin{array}{l}\text { Road and bridge } \\
\text { improvement program }\end{array}$ & $\begin{array}{l}\text { Improved roads and } \\
\text { bridges in isolated areas }\end{array}$ & $100 \%$ & $13 \%$ \\
\hline 6 & $\begin{array}{l}\text { Housing development } \\
\text { program }\end{array}$ & $\begin{array}{l}\text { Improving the quality of } \\
\text { livable houses }\end{array}$ & $100 \%$ & $80 \%$ \\
\hline 7 & $\begin{array}{l}\text { Road and bridge } \\
\text { rehabilitation/maintenance } \\
\text { program }\end{array}$ & $\begin{array}{l}\text { Maintaining the quality of } \\
\text { roads and bridges }\end{array}$ & $100 \%$ & $99 \%$ \\
\hline 8 & $\begin{array}{l}\text { Road and bridge construction } \\
\text { program }\end{array}$ & $\begin{array}{l}\text { Construction of roads } \\
\text { and bridges in isolated } \\
\text { areas }\end{array}$ & $100 \%$ & $82 \%$ \\
\hline 9 & $\begin{array}{l}\text { Road and bridge } \\
\text { information } \\
\text { system/database } \\
\text { development program }\end{array}$ & $\begin{array}{l}\text { Availability of road } \\
\text { and bridge database }\end{array}$ & $100 \%$ & $75 \%$ \\
\hline 10 & $\begin{array}{l}\text { Drainage / culvert } \\
\text { construction program }\end{array}$ & $\begin{array}{l}\text { Residential } \\
\text { settlements are free } \\
\text { from overflow and } \\
\text { inundation }\end{array}$ & $100 \%$ & $99 \%$ \\
\hline 11 & $\begin{array}{l}\text { Program for the } \\
\text { development and } \\
\text { management of irrigation } \\
\text { networks, swamps, and } \\
\text { other spatial and natural } \\
\text { resource management } \\
\text { networks }\end{array}$ & $\begin{array}{l}\text { Availability of irrigation } \\
\text { accompaniment } \\
\text { network, swamp, and } \\
\text { spatial planning as well } \\
\text { as natural resources }\end{array}$ & $100 \%$ & $95 \%$ \\
\hline 12 & $\begin{array}{l}\text { Sheet pile / talud / gabion } \\
\text { construction program }\end{array}$ & $\begin{array}{l}\text { Availability of beach } \\
\text { safety buildings }\end{array}$ & $100 \%$ & $99 \%$ \\
\hline 13 & $\begin{array}{l}\text { Rural infrastructure } \\
\text { development program }\end{array}$ & $\begin{array}{l}\text { Complete with rural road } \\
\text { facilities }\end{array}$ & $100 \%$ & $95 \%$ \\
\hline 14 & $\begin{array}{l}\text { Strategic and fast-growing } \\
\text { regional development } \\
\text { program }\end{array}$ & $\begin{array}{l}\text { Construction of soccer } \\
\text { fields and hoarding of } \\
\text { housing locations and } \\
\text { PLTG }\end{array}$ & $100 \%$ & $100 \%$ \\
\hline
\end{tabular}

Source: LAKIP PUPR Office of Yapen Islands Regency in 2019 
This study assumed that the un-optimal performance of the observed local organization proceeded from the un-optimal employee performance. As stated by Kim (2004), employees are a fundamental asset of good organizational performance. Furthermore, Tarmidi and Arsjah (2019) found that employee performance positively affects organizational performance.

The researchers conducted an initial survey by distributing questionnaires to 101 observed respondents through Google Form to determine the phenomena gap. The survey was to determine the respondents' assumed influencing factors of their low performance. The selection of these factors was based on previous studies examining similar local organizations' performance in various regions. Prior studies have found that some influencing factors are: leadership style (Tirtayasa, 2019; Bukit et al., 2019; Syihab et al., 2020), motivation (Bukit et al., 2019; Mariana et al., 2018), work environment (Djuwarto \& Hartono, 2017; Dhermawan et al., 2012), competence (Djuwarto \& Hartono, 2017; Mariana et al., 2018), organizational culture (Lumenta et al., 2019), job satisfaction: (Rosnaida \& Rahman, 2020), and workload or work stress (Utami et al., 2016). The results of the preliminary survey are as follows.

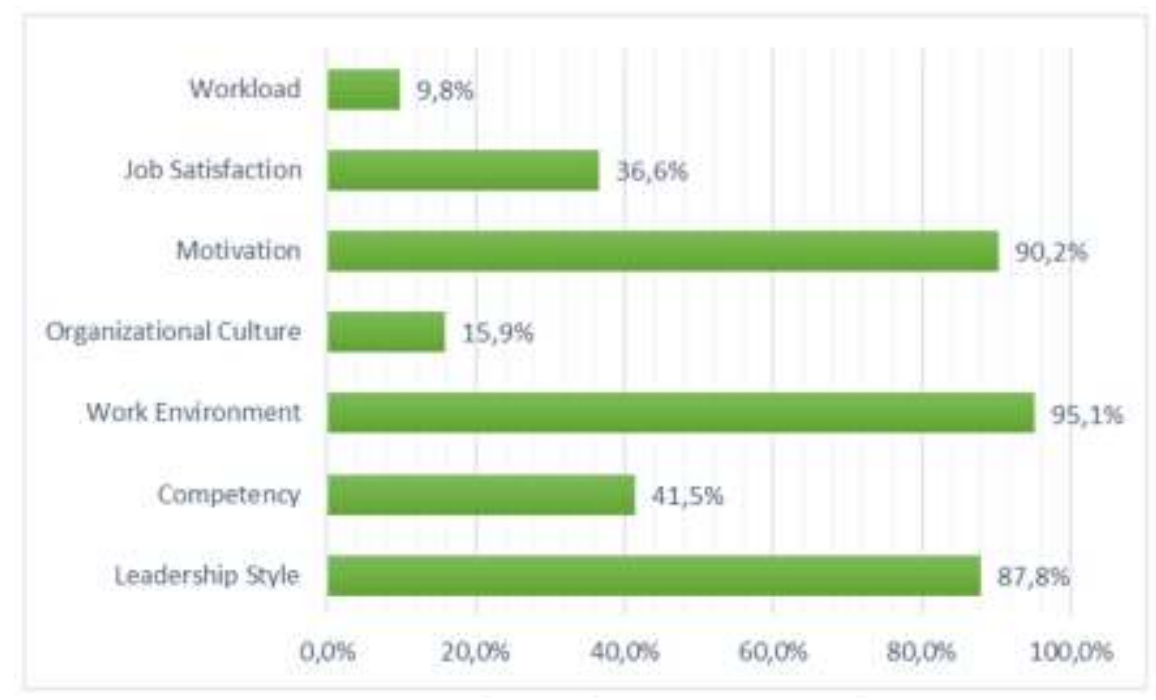

Figure 1. Results of Preliminary Survey Analysis

The results of the initial questionnaire analysis found that most respondents chose three factors, and the number exceeded $80 \%$ of respondents. The three factors are leadership style $(87.8 \%)$, motivation $(90.2 \%)$, and work environment $(95.1 \%)$. Therefore, this study will use these three factors as the observed variables to explore their influences on the performance of employees. Ohemeng et al. (2018), in their research, proves that leadership style plays an essential role in improving the quality of employee performance in the public sector. Previous researchers found that leadership style positively and significantly affected employee performance at similar local organizations in East Kutai, Jambi City, and Barru (Darmawan, 2015; Bukit et al., 2019; Syihab et al., 2020). This research will examine the specific leadership style, namely the participatory leadership style. A participatory leadership style selection is based on initial interviews with leaders at the observed local organization. Based on the researcher's observations, the application of the participatory leadership style has not been optimal because not all employees are given trust and control in carrying out their work.

In addition to leadership style, employees who have high work motivation tend to have good performance. Bukit et al. (2019) found that motivation had a significant effect on the performance of the PUPR Office employees in Palu and Jambi. More specifically, Mariana et al. (2018) found that internal motivation, which was dominated by the need for achievement, positively affected employee performance at a similar organization located in Bantaeng Regency. 
Based on the prior observations, employees at the observed organization do not yet have good motivation. Many of the observed employees feel that the salary they get has not been able to meet the needs of their families and do not fully feel safe working at the studied local organization. Therefore, motivational factors need to be investigated further.

The next factor is the work environment which also has a significant contribution in improving performance (Gardjito, 2014). Previous empirical findings have proven that the work environment positively affects employee performance at similar organizations in several regions of Indonesia, such as Semarang, and Manado (Djuwarto \& Hartono, 2017; Lumenta et al., 2019). The work environment at the observed organization (the PUPR Office of Yapen Islands Regency) is not good enough due to the old building and the need for new building facilities. Even some employees do not have their tables and chairs. In addition, the air circulation is also not good.

Researchers also found a research gap regarding leadership style, motivation, and work environment on employee performance. In addition to the positive influence, some researchers also found a negative and insignificant effect of leadership style (Tirtayasa, 2019), motivation (Dhermawan et al., 2012), and work environment (Warokka \& Febrilia, 2015) on the performance of similar organizations' employees in the regions of Indonesia. Therefore, further research is needed to ascertain the effect of these three variables on the performance of employees at the observed local organization. Based on the description above, researchers are interested in examining the factors of participatory leadership style, motivation, and work environment that affect the performance of employees at the PUPR Office of the Yapen Islands Regency.

\section{Review of Literatures}

\subsection{Performance}

Performance is the achievement of tasks that can be measured against the standards set by each organization. Performance does not come from the talent or ability of the employee but is the result of the talent and ability itself (Lie et al., 2019). Therefore, it can be concluded that performance results from work that a person has successfully carried out. It can be measured by the standards that each organization has set. Every employee certainly has different achievements from each other. This fact is due to the placement of different employees, depending on their abilities. This placement is a problematic factor by piling up each employee's challenges, culminating in employee performance (Jacobsen \& Bøgh Andersen, 2015).

\subsection{Participatory Leadership Style}

Leadership style has an important role that a leader must have in managing human resources (Liu et al., 2013). However, every leader has a different leadership style depending on the employee based on direction, empowerment, and decision-making power. For that, every leader needs to understand his employees' condition well (Iqbal et al., 2015). One of the most widely used leadership styles is the participatory leadership style. According to House (1996), participatory leaders have consultative behavior, such as asking subordinates to actively provide ideas before making a final decision, even though the final decision remains in the leader's hands. The main benefit of the participatory leadership style is that employees feel satisfied, motivated, and more skilled, leading to a lively, open work environment and encouraging employee creativity (Iqbal et al., 2015). 
Previous research found a positive and significant influence between participatory leadership style and employee performance (Makambe \& Moeng, 2020; Rana et al., 2019). According to Lumbasi et al. (2016), high employee performance is achieved when leaders involve their employees in consulting and decision-making. Therefore, referring to the theory and previous empirical findings, the first hypothesis proposed is:

H1: Participatory leadership style affects the performance of employees.

\subsection{Work Motivation}

Motivation is the most critical element for all organizations, both private and public, to achieve good performance. Motivation is one of the goals so that employees remain motivated to work following the job references and responsibilities given so that company goals can be adequately achieved (Dunggio \& Rachman, 2017). Leaders motivate employees to achieve effectiveness and efficiency in achieving company goals (Lukasik, 2017). According to Omolo (2015), motivation is the key to an organization's success to maintain its employees' performance and help the organization survive. Several previous studies have found that motivation affects employee performance (Dunggio \& Rachman, 2017; Twalib \& Kariuki, 2020). Therefore, referring to the theory and previous studies, the second hypothesis proposed in this study is: H2: Motivation affects the performance of employees.

\subsection{Work Environment}

A work environment is a place and environment in which employees work A conducive work environment will provide welfare for employees, which allows employees to carry out responsibilities that lead to higher productivity (Ollukkaran \& Gunaseelan, 2012). According to Dunggio and Rachman (2017), in achieving employee performance, companies must adapt to the condition and work environment, which is suitable and comfortable. Previous empirical findings prove a significant effect of the work environment on employee performance (Priarso et al., 2019; Riyanto et al., 2017). Therefore, based on the theory and findings of previous studies, the third hypothesis proposed in this study is:

H3: The work environment affects the performance

The three hypotheses proposed in this study are summarized in the following research model (Figure 2).

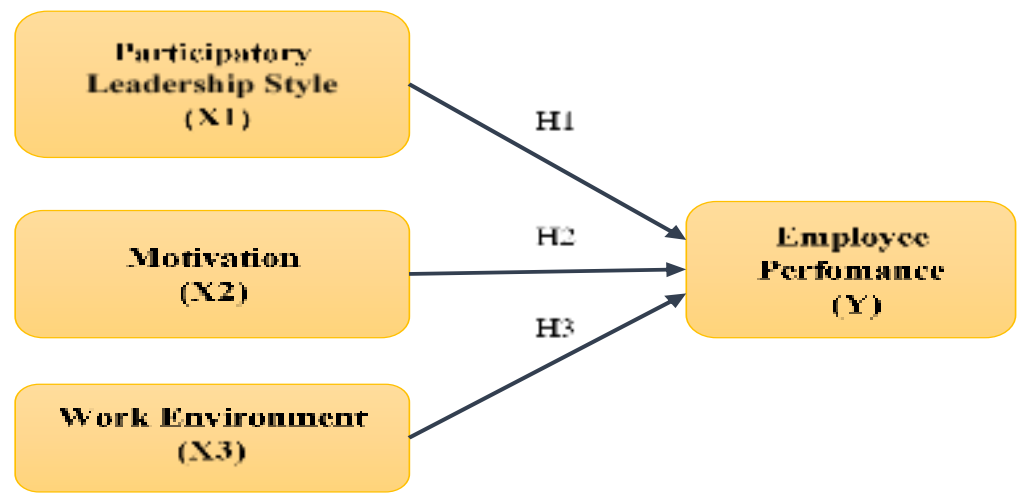

Figure 2. Research Model

This research is quantitative research in which the data obtained through a questionnaire research instrument concerning the theories of the variables of participatory leadership style, motivation, and work environment on employee performance. The population in this study were employees of the Department of Public Works and Public Housing (PUPR) of the Yapen Islands Regency. Because the population is not so large, with only 101 employees, the entire population is used as a sample or commonly referred to as the saturated sampling method. 
The research instrument used in this study was a questionnaire. Respondents' perceptions were measured using a 5-point Likert scale from 1-strongly disagree, 2-disagree, 3moderately agree, 4-agree, and 5-strongly agree. SPSS statistical program was used to analyze the data. The analytical method used is descriptive analysis with validity and reliability testing for the items in the questionnaire. It applied the classical assumption test and multiple linear regression analysis to determine the influence of independent variables (i.e., participatory leadership style, motivation, and work environment) on the dependent variable, namely employee performance.

\section{Results and Discussion}

The characteristics of respondents analyzed in this study include gender, last education, age, years of service, and civil servant groups at the Department of Public Works and Public Housing (PUPR) of Yapen Islands Regency. The results of the descriptive analysis of the characteristics of the respondents in table 2 show that the employees are dominated by male employees $(72.8 \%)$, the latest education level is S1 (40.59\%), are in the age range of 41-50 years ( $43.56 \%)$, having a working period of $11-15$ years $(33.66 \%)$, and the public officers' echelon $\mathrm{III} / \mathrm{c}$ and II/b $(17.82 \%)$.

Table 2. Description of Respondents Characteristics

\begin{tabular}{|c|c|c|c|}
\hline Category & Alternative Answer & $\begin{array}{c}\text { Number of } \\
\text { Respondents }\end{array}$ & Percent $(\%)$ \\
\hline \multirow{2}{*}{ Gender } & Male & 73 & $72.28 \%$ \\
\hline & Female & 28 & $27.72 \%$ \\
\hline \multirow{6}{*}{$\begin{array}{l}\text { Last Education } \\
\text { Level }\end{array}$} & Elementary School & 10 & $9.90 \%$ \\
\hline & Junior High School & 5 & $4.95 \%$ \\
\hline & Senior High School & 34 & $33.66 \%$ \\
\hline & Diploma III (D3) & 8 & $7.92 \%$ \\
\hline & Strata One (S1) & 41 & $40.59 \%$ \\
\hline & Strata Two (S2) & 3 & $2.97 \%$ \\
\hline \multirow{3}{*}{ Age } & $31-40$ Years & 38 & $37.62 \%$ \\
\hline & $41-50$ Years & 44 & $43.56 \%$ \\
\hline & $51-57$ Years & 19 & $18.81 \%$ \\
\hline \multirow{7}{*}{ Years of service } & 15 years & 22 & $21.78 \%$ \\
\hline & $6-10$ Years & 17 & $16.83 \%$ \\
\hline & $11-15$ Years & 34 & $33.66 \%$ \\
\hline & $16-20$ Years & 12 & $11.88 \%$ \\
\hline & $20-25$ Years & 5 & $4.95 \%$ \\
\hline & $26-30$ Years & 9 & $8.91 \%$ \\
\hline & $31-35$ Years & 2 & $1.98 \%$ \\
\hline \multirow{9}{*}{$\begin{array}{c}\text { Echelon } \\
\text { (Public Officer } \\
\text { Level) }\end{array}$} & $\mathrm{IV} / \mathrm{b}$ & 1 & $0.99 \%$ \\
\hline & $\mathrm{IV} / \mathrm{a}$ & 3 & $2.97 \%$ \\
\hline & $\mathrm{III} / \mathrm{d}$ & 13 & $12.87 \%$ \\
\hline & $\mathrm{III} / \mathrm{c}$ & 18 & $17.82 \%$ \\
\hline & $\mathrm{III} / \mathrm{b}$ & 11 & $10.89 \%$ \\
\hline & $\mathrm{III} / \mathrm{a}$ & 13 & $12.87 \%$ \\
\hline & $\mathrm{II} / \mathrm{d}$ & 6 & $5.94 \%$ \\
\hline & $\mathrm{II} / \mathrm{c}$ & 2 & $1.98 \%$ \\
\hline & $\mathrm{II} / \mathrm{b}$ & 18 & $17.82 \%$ \\
\hline
\end{tabular}




\begin{tabular}{lll}
$\mathrm{II} / \mathrm{a}$ & 2 & $1.98 \%$ \\
$\mathrm{I} / \mathrm{d}$ & 3 & $2.97 \%$ \\
$\mathrm{I} / \mathrm{c}$ & 2 & $1.98 \%$ \\
$\mathrm{I} / \mathrm{b}$ & 7 & $6.93 \%$ \\
$\mathrm{I} / \mathrm{d}$ & 2 & $1.98 \%$ \\
\hline
\end{tabular}

The results of the respondents' answers were categorized by calculating the maximum value minus the minimum value then divided by the number of class 5 so that the results of the interval were 0.8 (Riduwan, 2002). With an interval of 0.80 , the categorization system is as follows: 1.00-1.80 (very low); 1.81-2.60 (low); 2.61-3.40 (moderate); 3,41-4.20 (high); and 4.215.00 (very high).

Table 3. Distribution of Respondents' Opinions

\begin{tabular}{|c|c|c|c|c|c|c|c|c|c|}
\hline \multirow{3}{*}{\multicolumn{2}{|c|}{ Items }} & \multicolumn{5}{|c|}{ Alternative Opinions } & \multirow[t]{3}{*}{ Amount } & \multirow{3}{*}{$\begin{array}{l}\text { Average } \\
\text { Score }\end{array}$} & \multirow[t]{3}{*}{ Category } \\
\hline & & STS & TS & CS & $\mathbf{S}$ & SS & & & \\
\hline & & 1 & 2 & 3 & 4 & 5 & & & \\
\hline X1.1 & $\begin{array}{l}\text { The leader always } \\
\text { invites you to take } \\
\text { an active role in } \\
\text { the activities } \\
\text { carried out }\end{array}$ & 2 & 10 & 42 & 35 & 12 & 101 & 3.45 & High \\
\hline $\mathrm{X} 1.2$ & $\begin{array}{l}\text { The leader always } \\
\text { directs to be able to } \\
\text { work well together } \\
\text { in the work team } \\
\text { team }\end{array}$ & 0 & 5 & 54 & 31 & 11 & 101 & 3.48 & High \\
\hline $\mathrm{X} 1.3$ & $\begin{array}{l}\text { The leader always } \\
\text { invites and directs } \\
\text { to carry out the } \\
\text { work following the } \\
\text { rules that have } \\
\text { been set }\end{array}$ & 0 & 5 & 43 & 41 & 12 & 101 & 3.59 & High \\
\hline $\mathrm{X} 1.4$ & $\begin{array}{l}\text { The leader gives } \\
\text { you trust and } \\
\text { control in carrying } \\
\text { out your work }\end{array}$ & 4 & 36 & 34 & 21 & 6 & 101 & 2.89 & Moderate \\
\hline $\mathrm{X} 1.5$ & $\begin{array}{l}\text { The leader gives } \\
\text { what are the rights } \\
\text { as an employee } \\
\text { (salary and } \\
\text { allowances) }\end{array}$ & 0 & 0 & 18 & 52 & 31 & 101 & 4.13 & High \\
\hline X1.6 & $\begin{array}{l}\text { The leader always } \\
\text { asks for opinions } \\
\text { and input in solving } \\
\text { problems }\end{array}$ & 8 & 27 & 33 & 27 & 6 & 101 & 2.96 & Moderate \\
\hline $\mathrm{X} 1.7$ & $\begin{array}{l}\text { The leader wants } \\
\text { to be involved in } \\
\text { providing ideas, } \\
\text { innovating, and } \\
\text { being creative in } \\
\text { achieving goals }\end{array}$ & 0 & 7 & 53 & 36 & 5 & 101 & 3.39 & Moderate \\
\hline
\end{tabular}


X1.8 The leader always

invites and

involves in

$\begin{array}{llllll}8 & 36 & 36 & 17 & 4 & 101\end{array}$

$2.73 \quad$ Moderate

decision making

\begin{tabular}{|c|c|c|c|c|c|c|c|c|c|}
\hline & \multicolumn{7}{|c|}{ Average } & \multirow{2}{*}{$\begin{array}{l}3.33 \\
2.70\end{array}$} & \multirow{2}{*}{$\begin{array}{l}\text { Moderate } \\
\text { Moderate }\end{array}$} \\
\hline & $\begin{array}{l}\text { The income } \\
\text { earned can meet } \\
\text { the needs of the } \\
\text { family }\end{array}$ & 8 & 44 & 22 & 24 & 3 & 101 & & \\
\hline $\mathrm{X} 2.2$ & $\begin{array}{l}\text { You feel safe in } \\
\text { carrying out the } \\
\text { work at the place } \\
\text { where you work }\end{array}$ & 0 & 16 & 36 & 45 & 4 & 101 & 3.37 & High \\
\hline X2.3 & $\begin{array}{l}\text { You have a good } \\
\text { relationship with } \\
\text { the leaders }\end{array}$ & 0 & 1 & 32 & 57 & 11 & 101 & 3.77 & High \\
\hline $\mathrm{X} 2.4$ & $\begin{array}{l}\text { You have a work } \\
\text { team that prioritizes } \\
\text { love, belonging, } \\
\text { being well received, } \\
\text { and a sense of } \\
\text { friendship in carrying } \\
\text { out daily job }\end{array}$ & 0 & 0 & 32 & 59 & 10 & 101 & 3.78 & High \\
\hline $\mathrm{X} 2.5$ & $\begin{array}{l}\text { You receive } \\
\text { praise/thank you } \\
\text { from the leaders } \\
\text { when you } \\
\text { successfully } \\
\text { complete the job }\end{array}$ & 1 & 2 & 33 & 56 & 9 & 101 & 3.69 & High \\
\hline $\mathrm{X} 2.6$ & $\begin{array}{l}\text { Organizations } \\
\text { reward employees } \\
\text { who excel }\end{array}$ & 0 & 13 & 37 & 47 & 4 & 101 & 3.42 & High \\
\hline $\mathrm{X} 2.7$ & $\begin{array}{l}\text { You are always } \\
\text { allowed to develop } \\
\text { yourself by } \\
\text { attending } \\
\text { training/training }\end{array}$ & 0 & 2 & 46 & 48 & 5 & 101 & 3.55 & High \\
\hline $\mathrm{X} 2.8$ & $\begin{array}{l}\text { In carrying out the } \\
\text { work, you are } \\
\text { given the freedom } \\
\text { to be creative and } \\
\text { innovate }\end{array}$ & 1 & 4 & 32 & 61 & 3 & 101 & 3.60 & High \\
\hline
\end{tabular}

X3.1 Work facilities in

the form of an

office building at

$2 \quad 11 \quad 41$

the place of work

45

2

101

$3.34 \quad$ Moderate

are adequate

X3.2 Work facilities in

the form of

workspaces, tables,

and chairs at the

$0 \quad 10$

47

39

5

101

3.39

Moderate

workplace are

adequate 


\begin{tabular}{|c|c|c|c|c|c|c|c|c|c|}
\hline $\mathrm{X} 3.3$ & $\begin{array}{l}\text { The air circulation } \\
\text { in your workspace } \\
\text { has met the } \\
\text { standards }\end{array}$ & 0 & 6 & 45 & 46 & 4 & 101 & 3.48 & High \\
\hline X3.4 & $\begin{array}{l}\text { The need for a } \\
\text { temperature } \\
\text { control (AC) in } \\
\text { the room where } \\
\text { you work }\end{array}$ & 1 & 4 & 29 & 59 & 8 & 101 & 3.68 & High \\
\hline X3.5 & $\begin{array}{l}\text { Lighting from } \\
\text { sunlight has met } \\
\text { the requirements } \\
\text { for lighting needs } \\
\text { in your workspace }\end{array}$ & 0 & 4 & 44 & 52 & 1 & 101 & 3.50 & High \\
\hline X3.6 & $\begin{array}{l}\text { The lighting in the } \\
\text { work room is } \\
\text { adequate for lighting }\end{array}$ & 0 & 1 & 33 & 65 & 2 & 101 & 3.67 & High \\
\hline X3.7 & $\begin{array}{l}\text { At work, you are far } \\
\text { from noise so you } \\
\text { can concentrate on } \\
\text { work }\end{array}$ & 0 & 1 & 38 & 56 & 6 & 101 & 3.66 & High \\
\hline X3.8 & $\begin{array}{l}\text { At work, you do not } \\
\text { feel mechanical } \\
\text { vibrations (vehicle } \\
\text { /equipment) to } \\
\text { concentrate on work }\end{array}$ & 0 & 6 & 34 & 57 & 4 & 101 & 3.58 & High \\
\hline X3.9 & $\begin{array}{l}\text { The room where } \\
\text { you work is far } \\
\text { from bad smells so } \\
\text { you can concentrate } \\
\text { on work }\end{array}$ & 0 & 4 & 39 & 53 & 5 & 101 & 3.58 & High \\
\hline $\begin{array}{c}\text { X3.1 } \\
0\end{array}$ & $\begin{array}{l}\text { The color of the } \\
\text { walls of the } \\
\text { workspace is } \\
\text { appropriate so that } \\
\text { you feel comfortable } \\
\text { to work }\end{array}$ & 1 & 1 & 44 & 49 & 6 & 101 & 3.57 & High \\
\hline X3.11 & $\begin{array}{l}\text { Establish good } \\
\text { working } \\
\text { relationships with } \\
\text { leaders and co- } \\
\text { workers in } \\
\text { completing each } \\
\text { job setiap }\end{array}$ & 0 & 0 & 27 & 68 & 6 & 101 & 3.79 & High \\
\hline \multicolumn{8}{|c|}{ Average } & 3.57 & High \\
\hline Y.1 & $\begin{array}{l}\text { You do the job } \\
\text { accurately, neatly, } \\
\text { and rarely make } \\
\text { mistakes }\end{array}$ & 0 & 12 & 54 & 32 & 3 & 101 & 3.26 & Moderate \\
\hline Y.2 & $\begin{array}{l}\text { In completing the } \\
\text { work, you are } \\
\text { always guided by } \\
\text { the applicable } \\
\text { regulations so that } \\
\text { you have quality } \\
\text { work }\end{array}$ & 0 & 0 & 43 & 52 & 6 & 101 & 3.63 & High \\
\hline
\end{tabular}




\begin{tabular}{|c|c|c|c|c|c|c|c|c|c|}
\hline Y.3 & $\begin{array}{l}\text { You can achieve } \\
\text { the results of the } \\
\text { volume of work } \\
\text { following the } \\
\text { targets that have } \\
\text { been set }\end{array}$ & 1 & 17 & 44 & 36 & 3 & 101 & 3.23 & Moderate \\
\hline Y.4 & $\begin{array}{l}\text { You have the } \\
\text { knowledge that is } \\
\text { needed to do the } \\
\text { assigned work }\end{array}$ & 0 & 4 & 37 & 54 & 6 & 101 & 3.61 & High \\
\hline Y.5 & $\begin{array}{l}\text { Having extensive } \\
\text { knowledge is very } \\
\text { important in } \\
\text { carrying out the } \\
\text { work }\end{array}$ & 0 & 1 & 30 & 55 & 15 & 101 & 3.83 & High \\
\hline Y.6 & $\begin{array}{l}\text { There is support } \\
\text { from the } \\
\text { leadership as part } \\
\text { of the work team }\end{array}$ & 0 & 2 & 27 & 62 & 10 & 101 & 3.79 & High \\
\hline Y.7 & $\begin{array}{l}\text { In a work team, } \\
\text { fellow employees } \\
\text { support each other } \\
\text { both in terms of } \\
\text { data and } \\
\text { motivation to } \\
\text { complete work }\end{array}$ & 0 & 2 & 23 & 68 & 8 & 101 & 3.81 & High \\
\hline Y.8 & $\begin{array}{l}\text { You have } \\
\text { creativity in } \\
\text { completing work } \\
\text { effectively and } \\
\text { efficiently }\end{array}$ & 0 & 4 & 38 & 56 & 3 & 101 & 3.57 & High \\
\hline Y.9 & $\begin{array}{l}\text { The creativity that } \\
\text { you have provides } \\
\text { positive changes in } \\
\text { the organization } \\
\text { where you work }\end{array}$ & 0 & 6 & 37 & 53 & 5 & 101 & 3.56 & High \\
\hline Y.10 & $\begin{array}{l}\text { You have ideas } \\
\text { that can be used to } \\
\text { complete the work }\end{array}$ & 1 & 6 & 39 & 48 & 7 & 101 & 3.53 & High \\
\hline Y.11 & $\begin{array}{l}\text { You always take } \\
\text { the initiative to be } \\
\text { able to complete } \\
\text { the work without } \\
\text { the help of others }\end{array}$ & 2 & 8 & 44 & 41 & 6 & 101 & 3.41 & High \\
\hline Y.12 & $\begin{array}{l}\text { You try to be the } \\
\text { first person in } \\
\text { completing the } \\
\text { given job }\end{array}$ & 2 & 14 & 41 & 41 & 3 & 101 & 3.29 & Moderate \\
\hline
\end{tabular}

Note: $S T S=$ Strongly Disagree; $T S=$ Disagree; $C S=$ Moderately Agree; $S=$ Agree; $S S=$ Strongly Agree, X1

= Participative Leadership Style; $\mathrm{X} 2=$ Motivation; X3 =Working Environment; $Y=$ Employee Performance. 
From the results of the descriptive analysis of respondents' answers, it can be seen that the variables of motivation, work environment, and employee performance have an average value that is in the high category, namely $3.49,3.57$, and 3.54 , respectively. In contrast, the participatory leadership style variable has a value of 3.33 in the moderate category. This finding shows that the participatory leadership style has not been applied well enough at the observed local organization.

Table 4. Validity and Reliability Test Results

\begin{tabular}{lcc}
\hline Items & R Count & Cronbach's Alpha \\
\hline X1.1 & 0.906 & \\
X1.2 & 0.886 & \\
X1.3 & 0.852 & \\
X1.4 & 0.934 & \\
X1.5 & 0.716 & \\
X1.6 & 0.902 & \\
X1.7 & 0.856 & \\
X1.8 & 0.912 & \\
\hline X2.1 & 0.709 & \\
X2.2 & 0.713 & \\
X2.3 & 0.775 & \\
X2.4 & 0.806 & \\
X2.5 & 0.739 & \\
X2.6 & 0.769 & \\
X2.7 & 0.730 & \\
X2.8 & 0.627 & \\
\hline X3.1 & 0.726 & \\
X3.2 & 0.713 & \\
X3.3 & 0.629 & \\
X3.4 & 0.533 & \\
X3.5 & 0.558 & \\
X3.6 & 0.566 & \\
X3.7 & 0.693 & \\
X3.8 & 0.647 & \\
X3.9 & 0.682 & \\
X3.10 & 0.695 & \\
X3.11 & 0.710 & \\
\hline Y.1 & 0.706 & \\
Y.2 & 0.612 & \\
Y.3 & 0.663 & \\
Y.4 & 0.750 & \\
Y.5 & 0.494 & \\
Y.6 & 0.703 & \\
Y.7 & 0.715 & \\
Y.8 & 0.719 & \\
Y.9 & 0.763 & \\
Y.10 & 0.775 & \\
Y.11 & 0.798 & \\
Y.12 & 0.633 & \\
\hline & & \\
& & \\
\end{tabular}


Then the researcher conducted a validity test and a reliability test to test whether or not it was valid and whether or not the statements/questions from the questionnaires were made reliable. Product moment is a measuring tool used to test the validity by looking at the calculated r-value. The validity test results show that all statements/questions have a calculated $r$-value greater than the r-table, which is 0.1956 . This finding shows all valid statements/questionsfurthermore, the reliability test using Cronbach's alpha. The results of all reliability tests show that Cronbach's alpha value is more significant than 0.6 and indicates that all variables are said to be reliable.

Table 5. Classical Assumption Test Results

\begin{tabular}{ccccccc}
\hline \multicolumn{2}{c}{ Normality test } & \multicolumn{3}{c}{$\begin{array}{c}\text { Multicollinearity } \\
\text { Test }\end{array}$} & \multicolumn{2}{c}{ Heteroscedasticity Test } \\
\hline Kolmogorov Smirnov v & $\begin{array}{c}\text { asymp. } \\
\text { Sig }\end{array}$ & $\begin{array}{c}\text { Variabl } \\
\mathrm{e}\end{array}$ & Tolerance & VIF & Sig Value & $\begin{array}{c}\text { Sig. Value } \\
\text { limit }\end{array}$ \\
\hline \multirow{3}{*}{1.026} & & $\mathrm{X} 1$ & 0.904 & 1.106 & 0.451 & 0.05 \\
\cline { 3 - 7 } & \multirow{2}{*}{0.244} & $\mathrm{X} 2$ & 0.631 & 1.585 & 0.142 & 0.05 \\
\cline { 3 - 7 } & & $\mathrm{X} 3$ & 0.670 & 1,492 & 0.790 & 0.05 \\
\cline { 3 - 7 }
\end{tabular}

The classical assumption test was carried out to ensure that the data used were normally distributed. It also ensured that the data did not experience multicollinearity and had no heteroscedasticity problems. Normality test performed using Kolmogorov Smirnov. The results of these tests show the values obtained in Asymp. Sig of 0.244 is more significant than 0.05. This finding means that this result shows that the data is normally distributed. Then the multicollinearity test was carried out to find out whether the regression model studied correlated with the independent variables or not. The results of the multicollinearity test show that the tolerance value is close to 1 , and the VIF value is below 10. It means that there is no multicollinearity between the independent variables in this study. Furthermore, the heteroscedasticity test was undertaken to determine whether the data used had the same variance from one observation and another observation. Heteroscedasticity test using Glejser test. The conducted tests showed that the three independent variables had no statistically significant effect on the absolute value of the dependent variable. Thus, it can be concluded that there is no heteroscedasticity.

Table 6. Results of Multiple Regression Analysis and Hypothesis Testing

\begin{tabular}{|c|c|c|c|c|c|c|}
\hline \multirow{2}{*}{\multicolumn{2}{|c|}{ Model }} & \multicolumn{2}{|c|}{ Unstandardized Coefficients } & \multicolumn{3}{|l|}{$\begin{array}{c}\text { Standardized } \\
\text { Coefficients }\end{array}$} \\
\hline & & B & Std. Error & Beta & $\mathrm{t}$ & Sig. \\
\hline \multirow[t]{5}{*}{1} & (Constant) & 4,864 & 3.514 & & 1.384 & 0.169 \\
\hline & $\begin{array}{l}\text { Participatory } \\
\text { Leadership Style }\end{array}$ & 0.056 & 0.068 & 0.058 & 0.822 & 0.413 \\
\hline & Work motivation & 0.538 & 0.115 & 0.395 & 4,696 & 0.000 \\
\hline & Work environment & 0.539 & 0.102 & 0.433 & 5,305 & 0.000 \\
\hline & Adjusted R Square & 0.554 & & & & \\
\hline
\end{tabular}

a. Dependent Variable: Employee Performance

After the data is declared valid, reliable, and meets the classical assumption test, the multiple linear regression analysis tests are undertaken. The results of hypothesis testing show that the participatory leadership style variable has a statistical $t$ value of $0.822<\mathrm{t}$ table 1.660 with a significance level of $0.413>0.05$. These results indicate that the participatory leadership style variable has no significant effect on employee performance. This result rejects the first hypothesis. 
These findings are not in line with previous research, which found a significant effect of participatory leadership style on employee performance (Makambe \& Moeng, 2020; Rana et al., 2019). If viewed based on the respondents' answers, the participatory leadership style variable has the lowest average value compared to the other two independent variables (motivation and work environment), which is 3.33 and is categorized into the medium category. The items' mean values indicate that the participatory leadership style is not well applied in the observed local organization. The leaders have not been able to invite and involve employees in making decisions, have not been able to give trust and control to employees in carrying out their duties, and have not fully asked for employee opinions and input related to problem-solving. This finding aligns with Lor and Hassan (2017), who found the participatory leadership style not yet suitable to be applied to improve employee performance.

This negative result is in line with the study of Lam et al. (2015). They confirmed that the positive effect of participatory leadership could only be realized when the perceived magnitude of participatory leadership reaches a certain point that exceeds the moderate level (threshold). This level of effect should be supported by high information sharing. Therefore, it can be concluded that the amount of participatory leadership has not been felt by employees so that it does not affect employee performance. In addition, the basis of the participatory leadership style is to emphasize the behavior of the leader with his subordinates (followers). Thus, to know more clearly about the influence of participatory leadership style, it is necessary to analyze the maturity level of the employees.

Furthermore, testing the second hypothesis shows the value of the $t$ statistic on the motivation variable is $4.696>\mathrm{t}$ table 1.660 with a significance level of $0.000<0.05$. Thus, the second hypothesis is supported, and it is proven that motivation has a significant influence on employee performance. This finding aligns with previous research, which found a significant positive relationship between work motivation variables and employee performance variables (Twalib and Kariuki, 2020).

Employees at the observed organization are most motivated by fulfilling social needs and appreciation from leaders. These results support the theory of need motivation proposed by Maslow (1943). The leaders also met the employees' need for appreciation by praising or thanks them when they complete the job. With the fulfillment of these needs, employees are motivated and ultimately affects the increase in performance.

Finally, testing the third hypothesis shows that the statistical $\mathrm{t}$ value on the work motivation variable is $5.305>\mathrm{t}$ table 1.660 with a significance level of $0.000<0.05$. This finding indicates that the work environment variable indirectly influences the employee performance variable and supports the third hypothesis. This finding aligns with previous studies, which found a significant positive relationship between work environment variables and employee performance variables (Priarso et al., 2019; Riyanto et al., 2017).

Researchers conducted the $\mathrm{R}^{2}$ test (coefficient of determination) to measure the ability of the regression model with participatory leadership style variables (X1), motivation (X2), and work environment (X3) in explaining variations in employee performance variables $(\mathrm{Y})$. The results of the $\mathrm{R}^{2}$ test (coefficient of determination) show the Adjusted $\mathrm{R}$ Square value of 0.554 . This finding means that the model capability of the participatory leadership style variable (X1), motivation (X2), and work environment (X3) can affect the variation of employee performance variable $(\mathrm{Y})$ by $55.4 \%$, and the remaining $44.6 \%$ is influenced by other independent variables not examined in this study. 


\section{Conclusion}

This study examines the variables of participatory leadership style, motivation, and work environment on employee performance at the Public Works and Public Housing (PUPR) Office of the Yapen Islands Regency. The results of the research proceed following conclusions: (1) Participatory leadership style has no significant effect on employee performance; (2) work motivation has a significant effect on employee performance; and (3) the work environment has a significant effect on the performance of employees.

This study provides some critical findings and implications on the work practice of the Public Works Department of the Yapen Islands Regency. Leaders at the observed local organization need to improve the implementation of participatory leadership styles by involving and giving trust to employees to provide opinions and participate in problem-solving and decision-making. It would be good to provide adequate facilities so that employees can innovate and be creative. Furthermore, the leadership also needs to provide additional fees for activities and fees outside of working hours (overtime) and increase security in the office area for their employees to feel safe-providing facilities in the form of construction of new buildings.

In conducting this study, the researcher found several limitations. First, this study only examined the direct influence of leadership style, motivation, and work environment on employee performance. Thus, this study cannot explain or provide an in-depth description. Since the finding reveals no significant effect, it cannot explain whether it does not have an effect at all or can affect other intermediary variables. Second, this study only uses a small number of samples not to be generalized to a more extensive research object. Third, this study only examines the effect of participatory leadership style, motivation, and work environment on employee performance. Many other factors may also affect employee performance. Therefore, further researchers can examine other variables that are considered to affect employee performance. If still using the observed variables for further studies, it would be suitable to examine the mediating and moderating effects.

\section{References}

Bukit, P., Yamali, F. R., \& Ananda, R. (2019). Pengaruh Gaya Kepemimpinan terhadap Kinerja pegawai dengan Motivasi dan Disiplin kerja sebagai variabel intervening pada Dinas Pekerjaan Umum Dan Perumahan Rakyat Provinsi Jambi. J-MAS (Jurnal Manajemen dan Sains), 4(2), 413-422.

Darmawan, I. (2015). Pengaruh Gaya Kepemimpinan terhadap Kinerja Pegawai Pada Kantor Dinas Pekerjaan Umum Kabupaten Kutai Timur. PREDIKSI, 1(1).

Dhermawan, A. A. N. B., Sudibya, I. G. A., \& Utama, I. W. M. (2012). Pengaruh motivasi, lingkungan kerja, kompetensi, dan kompensasi terhadap kepuasan kerja dan kinerja pegawai di lingkungan kantor Dinas Pekerjaan Umum Provinsi Bali. Jurnal Manajemen, Strategi Bisnis, dan Kewirausahaan, 6(2), 173-184.

Djuwarto, I., \& Hartono, S. (2017). Pengaruh Insentif, Kompetensi, dan Lingkungan Kerja terhadap Kinerja Pegawai Dinas Pekerjaan Umum Kabupaten Sukoharjo. Jurnal Akuntansi dan Pajak, 18(1), 84-93.

Dunggio, T., \& Rachman, A. (2017). Influence Of Leadership, Motivation An Work EnviromentOn The Performance Of Employees In The Secretariat Department Of Highways South Sulawesi Province (Pengaruh Kepemimpinan, Motivasi dan Lingkungan Kerja Terhadap Kinerja Karyawan Di Sekretariat Dinas Bi. Internal Communication \& Organizational Behavior Ejournal, 8(6), 1-17. https://doi.org/10.2139/ssrn.2922281 
Fatihudin, D. (2018). The Effect of Work Environment on Employee Performance Through the Job Satisfaction in Drinking Water Company Pandaan Indonesia. International Journal of Management and Economics Invention, 4(11), 1982-1988. https://doi.org/10.31142/ijmei/v4i11.0

Gardjito, A. H. (2014). Pengaruh Motivasi Kerja Dan Lingkungan Kerja Terhadap Kinerja Karyawan (Studi pada Karyawan Bagian Produksi PT. Karmand Mitra Andalan Surabaya). Jurnal administrasi bisnis, 13(1), 1-8.

House, R. J. (1996). House-Path-goal theory of leadership: Lessons, Legacy, and AReformulated Theory pdf. Leadership Quarterly, 7(3), 323-352.

Iqbal, N., Anwar, S., \& Haider, N. (2015). Effect of leadership style on employee performance. Arabian Journal of Business and Management Review, 5(5), 1-6.

Jacobsen, C. B., \& Andersen, L. B. (2015). Is Leadership in the Eye of the Beholder? A Study of Intended and Perceived Leadership Practices and Organizational Performance. Public Administration Review, 75(6), 829-841. https://doi.org/10.1111/puar.12380

Jurnali, T., \& Siti-Nabiha, A. K. (2015). Performance management system for local government: The Indonesian experience. Global Business Review, 16(3), 351-363. https://doi.org/10.1177/0972150915569923

Kim, S. (2004). Individual-level factors and organizational performance in government organizations. Journal of public administration research and theory, 15(2), 245-261. https://doi.org/10.1093/jopart/mui013

Lam, C. K., Huang, X., \& Chan, S. C. H. (2015). The threshold effect of participative leadership and the role of leader information sharing. Academy of Management Journal, 58(3), 836-855.

Lie, D., Dharma, E., \& Sudirman, A. (2019). The Impact of Work Discipline and Work Ethic on the Teacher Performance of Sultan Agung Pematangsiantar Private Middle School Teachers T . A . 2018 / 2019. International Journal of Business Studies, 3(3), 125-135.

Liu, Z., Cai, Z., Li, J., Shi, S., \& Fang, Y. (2013). Leadership style and employee turnover intentions: A social identity perspective. Career Development International, 18(3), 305324. https://doi.org/10.1108/CDI-09-2012-0087

Lor, W., \& Hassan, Z. (2017). The influence of leadership on employee performance among jewelry artisans in Malaysia. International Journal of Accounting, Business \& Management, 5(1), 14-33.

Lukasik, K. (2017). The Impact Of Training On Employees Motivation In SMEs Industry. Zeszyty Naukowe Politechniki Częstochowskiej Zarządzanie, 28(1), 96-109. https://doi.org/10.17512/znpcz.2017.4.1.08

Lumbasi, G. W., K'Aol, G. O., \& Ouma, C. A. (2016). The Effect of Participative Leadership Style On The Performance of COYA Senior Managers in Kenya. Journal of Management, 4(5), 1-12.

Lumenta, M. E., Sepang, J. L., \& Tawas, H. N. (2019). Pengaruh Gaya Kepemimpinan, Budaya Organisasi dan Lingkungan Kerja Terhadap Kinerja Pegawai di Dinas Pekerjaan Umum dan Penataan Ruang Kota Manado. Jurnal Emba: Jurnal Riset Ekonomi, Manajemen, Bisnis dan Akuntansi, 7(1), 1-10.

Makambe, U., \& Moeng, G. J. M. (2020). The effects of leadership styles on employee performance: a case of a selected commercial bank in Botswana. Annals of Management and Organization Research, 1(1), 39-50. https://doi.org/10.35912/amor.v1i1.274

Mariana, N. N., Umar, A., \& Tamsah, H. (2018). Pengaruh Kompensasi, Kompetensi dan Motivasi terhadap Kinerja Pegawai pada Dinas Pekerjaan Umum dan Penataan Ruang di Kabupaten Bantaeng. YUME: Journal of Management, 1(2), 130-150.

Maslow, A. H. (1943). A theory of human motivation. Psychological Review, 50(4), 370-396. https://doi.org/10.1037/h0054346

Nabawi, R. (2019). Pengaruh Lingkungan Kerja, Kepuasan Kerja dan Beban Kerja Terhadap Kinerja Pegawai. Maneggio: Jurnal Ilmiah Magister Manajemen, 2(2), 170-183. 
Ohemeng, F. L. K., Amoako-Asiedu, E., \& Obuobisa Darko, T. (2018). The relationship between leadership style and employee performance. International Journal of Public Leadership, 14(4), 274-296. https://doi.org/10.1108/ijpl-06-2017-0025

Ollukkaran, B. A., \& Gunaseelan, R. (2012). A Study on The Impact Of Work Environment on Employee Performance. Namex International Journal of Management Research, 2(2), 72-85.

Omolo, P. A. (2015). Effect of motivation on employee performance of commercial banks in Kenya: A case study of Kenya Commercial Bank in Migori County. International Journal of Human Resource Studies, 5(2), 87. https://doi.org/10.5296/ijhrs.v5i2.7504

Priarso, M. T., Diatmono, P., \& Mariam, S. (2019). the Effect of Transformational Leadership Style, Work Motivation, and Work Environment on Employee Performance That in Mediation By Job Satisfaction Variables in Pt. Gynura Consulindo. Business and Entrepreneurial Review, 18(2), 165. https://doi.org/10.25105/ber.v18i2.5334

Rana, Rozy, Ka'ol, G., \& Kirubi, M. (2019). Effect of Participative Leadership Style on Employee Performance of Coffee Trading Companies in Kenya. Journal of Human Resource and Leadership, 4(2), 29-57.

Riduwan. (2002). Skala Pengukuran Variabel-Variabel Penelitian. Bandung: Alfabeta.

Riyanto, S., Sutrisno, A., \& Ali, H. (2017). The Impact of Working Motivation and Working Environment on Employees Performance in Indonesia Stock Exchange. International Review of Management and Marketing, 7(3), 342-348.

Rosnaida, R., \& Rahman, A. (2020). Pengaruh Gaya Kepemimpinan dan Kepuasan Kerja terhadap Kinerja Pegawai Pada Dinas Pekerjaan Umum Kabupaten Asahan. Seminar Nasional Multi Disiplin Ilmu Universitas Asahan.

Sugianto, D. (2017). Blak-blakan MenPan RB Soal Kinerja Pegawai. Finance.detik.com. https:// finance.detik.com/wawancara-khusus/d-3522331/blak-blakan-menpan-rbsoal-kinerja-pns

Suyuti, M. R., \& Kasmita, M. (2018). Improving Discipline Of Regional Civil Servants BT. 1st International Conference on Social Sciences (ICSS 2018), 1092-1094. https://doi.org/https://doi.org/10.2991/icss-18.2018.230

Syihab, S., Razak, M., \& Hidayat, M. (2020). Pengaruh Semangat Kerja, Gaya Kepemimpinan dan MotivasitTerhadap Kinerja Pegawai Dinas Pekerjaan Umum dan Penataan Ruang Kabupaten Barru. AkMen JURNAL ILMIAH, 17(2), 194-204.

Tarmidi, D., \& Arsjah, R. (2019). Employee and Organizational Performance: Impact of Employee Internal and External Factors, Moderated by Online Application. Journal of Resources Development and Management, 57, 30-37. https://doi.org/10.7176/JRDM/57-04

Tirtayasa, S. (2019). Pengaruh Kepemimpinan, Budaya Organisasi, Dan Motivasi Terhadap Kinerja Pegawai. Maneggio: Jurnal Ilmiah Magister Manajemen, 2(1), 45-54.

Twalib, M. H., \& Kariuki, M. M. (2020). Influence Of Motivation On Employee Performance At Telkom Kenya Limited. International Journal of Business Social Sciences \& Education, 2(11), 421-431.

Utami, L., Sarianti, R., \& Mesta, H. A. (2016). Pengaruh Gaya Kepemimpinan dan Stress Kerja terhadap Kinerja Pegawai Pada Dinas Pekerjaan Umum Kota Padang. Jurnal Praktik Bisnis, 4(1), 51-60.

Wahjusaputri, S., \& Fitriani, S. (2017). Competency Development of Civil State Apparatus in Term of Human Resource Management. International Conference on Learning Innovation (ICLI 2017). https:// doi.org/10.2991/icli-17.2018.6

Warokka, A., \& Febrilia, I. (2015). Work-family conflict and job performance: Lesson from a Southeast Asian emerging market. Journal of Southeast Asian Research, 5(1), 1-14. Article ID 420802. DOI: $10.5171 / 2015.420802$ 